\title{
UJI ANTIMIKROBA MINYAK ATSIRI MASOYI (Massoia aromatica) TERHADAP BAKTERI Streptococcus mutans
}

\author{
Rollando Rollando, Yohan Susilo Adi Prasetyo, Rehmadanta Sitepu \\ Program Studi Farmasi, Fakultas Sians dan Teknologi, Universitas Ma Chung, Malang, Indonesia
}

Kata Kunci :

Karang gigi, minyak atsiri, masoyi (Massoia aromatica),

Streptococcus mutans

\section{ABSTRAK}

Karang gigi merupakan salah satu keadaan patologis dari gigi. Salah satu penyebab karang gigi adalah bakteri Streptococcus mutans. Bakteri tersebut tidak bekerja sendiri tetapi didukung oleh beberapa faktor lainnya yaitu host (gigi dan saliva), substrat (makanan), dan waktu. Salah satu cara yang dapat dilakukan dalam pencegahan tumbuhnya karang gigi adalah dengan mengontrol akumulasi plak pada permukaan gigi. Tumbuhan masoyi merupakan salah satu tumbuhan yang tumbuh di Indonesia. Dari kajian teoritis yang ada, minyak atsiri masoyi (Massoia aromatica) mengandung senyawa yang mampu menghambat pertumbuhan bakteri. Penelitian ini bertujuan untuk mengetahui efektifitas minyak atsiri masoyi (Massoia aromatica) sebagai antibakteri terhadap Streptococcus mutans dengan melihat nilai KBM (Kadar Bunuh Minimum) dan KHM (Kadar Hambat Minimum). Penentuan nilai KBM dan KHM dilakukan metode kualitatif dan kuantitatif. Pada pengujian dengan metode kualitatif dilakukan disc diffusion test, metode dilusi cair, dan metode dilusi padat. Sedangkan pada pengujian kuantitatif dilakukan metode mikrodilusi. Penelitian ini menggunakan 8 konsentrasi yaitu 2000, 1000, 500, 250, $125,62,5,31,25$, dan 15,625 $\mu \mathrm{g} / \mathrm{mL}$. Hasil penelitian dengan metode kualitatif menunjukkan nilai KHM didapatkan pada konsentrasi $500 \mu \mathrm{g} / \mathrm{mL}$ dan nilai KBM didapatkan pada konsentrasi lebih dari 2000 $\mu \mathrm{g} / \mathrm{mL}$. Hasil penelitian dengan metode kuantitatif menunjukkan nilai IC50 85,047 $\mu \mathrm{g} / \mathrm{mL}$ dan IC90 $491,481 \mu \mathrm{g} / \mathrm{mL}$. Kesimpulan dari penelitian ini adalah minyak atsiri masoyi (Massoia aromatica) terbukti dapat menghambat pertumbuhan bakteri Streptococcus mutans.

\section{Masuk 22-05-2019 \\ Revisi 10-11-2019 \\ Diterima 19-11-2019}

Korespondensi

\section{Rollando Rollando}

ro.llando@machung.ac.id

Copyright

(C) 2019 Majalah Farmasi Farmakologi Fakultas

Farmasi - Makassar

Diterbitkan tanggal 19-11-2019

Dapat Diakses Daring Pada:

http://journal.unhas.ac.id /index.php/mff

\section{PENDAHULUAN}

Infeksi merupakan salah satu masalah yang serius dalam bidang kesehatan khususnya kesehatan gigi yang terus berkembang di Indonesia. Salah satu penyebab penyakit infeksi adalah bakteri. Bakteri membuat suatu pertahanan diri dengan membentuk suatu lapisan lendir yang disebut dengan biofilm. Mikroorganisme mampu berkembang dengan cara yang kompleks dalam membentuk morfologi baru yang tumbuh pada permukaan yang dikenal sebagai biofilm. Biofilm dianggap sebagai mediator utama infeksi dengan perkiraan kejadian infeksi sebesar 80\% (1).

Biofilm gigi diproduksi oleh komunitas bakteri dengan keanekaragaman hayati yang besar kurang lebih sebanyak 700 spesies bakteri. Dalam 24 jam pertama kolonisasi, bakteri streptokokus oral membentuk 60\% sampai 90\% biomassa plak supragingiva. Streptococcus mutans merupakan bakteri pembentuk biofilm dan dianggap sebagai agen etiologi utama dari karies gigi manusia. Streptococcus mutans memiliki berbagai kemampuan untuk menjajah permukaan gigi dan dalam kondisi tertentu terdapat dalam jumlah besar pada industri biofarmasi kariogenik dan membentuk biofilm dengan organisme lain, termasuk streptokokus dan bakteri lainnya. Streptococcus mutans menghasilkan enzim glukosil transferase (GTF) yang dapat mensintesis glukan dari bagian glukosa sukrosa yang menyebabkan kariogenisitas patogen gigi (2).
Salah satu tanaman obat yang dapat dimanfaatkan oleh masyarakat Indonesia adalah tanaman Masoyi. Tumbuhan Masoyi dimanfaatkan masyarakat Indonesia untuk mengobati beberapa penyakit seperti diare, demam, keputihan, kejang perut, dan pasca persalinan. Penelitian yang sudah pernah ada menyatakan bahwa tumbuhan Masoyi memiliki kandungan minyak atsiri yang dapat diperoleh dari kulit batang, batang, dan buah tanaman Masoyi (Rali et al, 2007). Minyak atsiri yang diperoleh dari kulit batang tumbuhan Masoyi dapat menghambat pembentukan biofilm oleh bakteri Staphylococcus aureus sebesar 50\% dengan konsentrasi $0,03 \% \mathrm{v} / \mathrm{v}$, sedangkan penggunaan minyak atsiri dari kulit batang tumbuhan Masoyi dengan konsentrasi 0,12\% v/v dapat mengganggu biofilm yang sudah terbentuk sebesar $50 \%$ (3).

Sejauh ini efektifitas dan daya hambat antibakteri minyak atsiri dari ekstrak tumbuhan Masoyi (Massoia aromatica) terhadap bakteri Streptococcus mutans pada jaringan keras gigi belum banyak diteliti. Oleh karena itu, penelitian ini dibuat untuk mengetahui efektifitas antimikroba Minyak Atsiri Masoyi (Massoia aromatica) terhadap bakteri Streptococcus mutans. Harapannya adalah Minyak Atsiri Masoyi (Massoia aromatica) dapat digunakan sebagai antimikroba terhadap pertumbuhan bakteri Streptococcus mutans penyebab karang gigi. 


\section{METODE PENELITIAN}

\section{Alat dan Bahan}

Peralatan yang digunakan dalam penelitian ini adalah autoklaf (AC-300AE, Tiyoda Manufacturing Co. Ltd.), ose, lampu bunsen, cawan petri, microtiter plate 96-well, microtiter reader, pinset, tabung reaksi (Pyrex-Germany dan Iwaki), tabung eppendorf, inkubator (Sakura, Jepang), spektrofotometer UV-Vis, pipet, mikropipet 10-1000 $\mu \mathrm{L} ; 1$ $10 \mu \mathrm{L}$ (Acura 825, Socorex), rak tabung reaksi, spidol, kertas label, dan vortex.

Bahan yang digunakan dalam penelitian ini adalah minyak atsiri Massoia aromatica, aquadest, DMSO, bakteri Streptococcus mutans ATTC 1576, media nutrient agar (NA), media nutrient broth (NB), kontrol positif berupa streptomisin dan obat kumur komersil, alkohol 70\%.

\section{Prosedur Kerja}

\section{Pembuatan Larutan Minyak Atsiri Masoyi}

Pembuatan larutan uji dibuat dengan mengencerkan Minyak Atsiri Masoyi (Massoia aromatica) dalam beberapa konsentrasi yaitu $2000 \mu \mathrm{g} / \mathrm{mL}, 1000 \mu \mathrm{g} / \mathrm{mL}, 500 \mu \mathrm{g} / \mathrm{mL}, 250$ $\mu \mathrm{g} / \mathrm{mL}, 125 \mu \mathrm{g} / \mathrm{mL}, 62,5 \mu \mathrm{g} / \mathrm{mL}, 31,25 \mu \mathrm{g} / \mathrm{mL}$, dan 15,625 $\mu \mathrm{g} / \mathrm{mL}$ dengan menambahkan DMSO. Kemudian dibuat juga kontrol negatif (KN) yaitu biakan bakteri Streptococcus mutans dan kontrol positif (KP) yaitu larutan obat kumur komersial, larutan antibiotik streptomisin dan $1 \mathrm{~mL}$ Minyak Atsiri Masoyi 100\%.

\section{Pembiakan Bakteri Streptococcus mutans Dengan Media} NB

Bakteri Streptococcus mutans dibiakkan pada medium cair dengan menggunakan media nutrient broth (NB) selama $1 \mathrm{x}$ 24 jam pada suhu $37^{\circ} \mathrm{C}$.

\section{Uji Antibakteri dengan Metode Disc Diffusion Test}

Pengujian aktivitas antimikroba dilakukan metode disc diffusion test. Mikroba uji yang digunakan Streptococcus mutans. Dibuat seri konsentrasi larutan uji $2000 \mu \mathrm{g} / \mathrm{mL}$, $1000 \mu \mathrm{g} / \mathrm{mL}, 500 \mu \mathrm{g} / \mathrm{mL}, 250 \mu \mathrm{g} / \mathrm{mL}, 125 \mu \mathrm{g} / \mathrm{mL}, 62,5$ $\mu \mathrm{g} / \mathrm{mL}, 31,25 \mu \mathrm{g} / \mathrm{mL}$, dan 15,625 $\mu \mathrm{g} / \mathrm{mL}$. Sebanyak $5 \mu \mathrm{L}$ senyawa uji dengan delapan konsentrasi tersebut diteteskan ke paper disc. Sebelum ditempelkan pada media nutrient agar (NA) yang sudah berisi bakteri uji, paper disc yang berisi senyawa ditunggu sampai kering, yang menandakan pelarutnya sudah menguap. Digunakan kontrol positif ampisilin $10 \mathrm{mg} / \mathrm{mL}$ dan $5 \mu \mathrm{L}$ obat kumur komersil, kontrol minyak $5 \mu \mathrm{L}$ Minyak Atsiri Masoyi 100\%, dan kontrol negatif $5 \mu \mathrm{L}$ etanol absolut steril (harus diuapkan). Kultur bakteri uji diinkubasi selama 24 jam, diamati zona hambatan di sekeliling paper disc.

\section{Uji Antibakteri dengan Penentuan Nilai KHM}

Penentuan nilai KHM (Kadar Hambat Minimum) dilakukan dengan menggunakan $2 \mathrm{ml}$ media NB (nutrient broth) yang dimasukkan ke dalam tabung reaksi, kemudian ditambahkan dengan larutan uji dengan konsentrasi $2000 \mu \mathrm{g} / \mathrm{mL}, 1000$ $\mu \mathrm{g} / \mathrm{mL}, 500 \mu \mathrm{g} / \mathrm{mL}, 250 \mu \mathrm{g} / \mathrm{mL}, 125 \mu \mathrm{g} / \mathrm{mL}, 62,5 \mu \mathrm{g} / \mathrm{mL}$, $31,25 \mu \mathrm{g} / \mathrm{mL}$, dan 15,625 $\mu \mathrm{g} / \mathrm{mL}$ sebanyak $1 \mathrm{ml}$, kemudian ditambahkan $1 \mathrm{ml}$ biakan bakteri Streptococcus mutans. Kontrol positif dibuat dengan menggunakan media NB sebanyak $2 \mathrm{ml}$ yang ditambahkan dengan $1 \mathrm{ml}$ antibiotik streptomisin $10 \mathrm{mg} / \mathrm{mL}$, kemudian ditambahkan $1 \mathrm{ml}$ biakan bakteri Streptococcus mutans. Sedangkan untuk membuat kontrol negatif, dilakukan dengan menambahkan 2 ml biakan bakteri Streptococcus mutans ke dalam $2 \mathrm{ml}$ media NB. Setelah itu, semua larutan uji, kontrol positif dan kontrol negatif diinkubasi selama 1 hari (24 jam), kemudian diamati kekeruhan pada larutan. Parameter yang digunakan adalah kekeruhan pada larutan uji.

\section{Uji Antibakteri dengan Penentuan Nilai KBM}

Uji penentuan nilai KBM (Kadar Bunuh Minimum) dilakukan dengan cara menggoreskan sebanyak satu ose larutan uji yang digunakan untuk uji penentuan nilai KHM pada media NA (nutrient agar) yang sudah disiapkan di dalam cawan petri. Larutan yang digunakan adalah larutan uji penentuan KHM yang bening/tidak ada tanda-tanda pertumbuhan bakteri Streptococcus mutans. Kemudian diinkubasi selama 1 hari (24 jam). Parameter yang digunakan adalah ada atau tidaknya pertumbuhan bakteri pada media agar tersebut yang ditandai dengan ada atau tidaknya daerah atau bintikbintik berwarna putih pada media agar.

\section{Uji Efektifitas Antibakteri dengan Metode Mikrodilusi}

Uji penentuan nilai $\mathrm{IC}_{50}$ dan $\mathrm{IC}_{90}$ dilakukan dengan metode mikrodilusi yang menggunakan microplate GREINER $96 \mathrm{U}-$ BOTTOM. Sumuran-sumuran yang ada pada plate akan diisi dengan larutan uji (konsentrasi $2000 \mu \mathrm{g} / \mathrm{mL}, 1000 \mu \mathrm{g} / \mathrm{mL}$, $500 \mu \mathrm{g} / \mathrm{mL}, 250 \mu \mathrm{g} / \mathrm{mL}, 125 \mu \mathrm{g} / \mathrm{mL}, 62,5 \mu \mathrm{g} / \mathrm{mL}, 31,25$ $\mu \mathrm{g} / \mathrm{mL}$, dan $15,625 \mu \mathrm{g} / \mathrm{mL}$ ), media NB, suspensi bakteri Streptococcus mutans, obat kumur komersial, dan larutan antibiotik streptomisin.

Nilai IC50 dan IC90 dilakukan dengan cara ke dalam sumuran dimasukkan $50 \mu \mathrm{L}$ media NB, $50 \mu \mathrm{L}$ suspensi bakteri uji yang telah disesuaikan kekeruhannya dengan standar McFarland 0,5, dan $100 \mu \mathrm{L}$ larutan uji dengan seri konsentrasi 2000 $\mu \mathrm{g} / \mathrm{mL}, 1000 \mu \mathrm{g} / \mathrm{mL}, 500 \mu \mathrm{g} / \mathrm{mL}, 250 \mu \mathrm{g} / \mathrm{mL}, 125 \mu \mathrm{g} / \mathrm{mL}$, $62,5 \mu \mathrm{g} / \mathrm{mL}, 31,25 \mu \mathrm{g} / \mathrm{mL}$, dan $15,625 \mu \mathrm{g} / \mathrm{mL}$. Sebagai kontrol minyak dimasukkan ke sumuran $100 \mu \mathrm{L}$ Minyak Atisiri Masoyi 100\%, kontrol bakteri uji digunakan $200 \mu \mathrm{L}$ bakteri uji, kontrol positif (3 sumuran) digunakan larutan streptomisin $10 \mathrm{mg} / \mathrm{mL}$ sebanyak $100 \mu \mathrm{L}$ dan bakteri uji sebanyak $100 \mu \mathrm{L}$, dan kontrol positif (2 sumuran) digunakan larutan obat kumur komersil sebanyak $100 \mu \mathrm{L}$ dan bakteri uji sebanyak $100 \mu \mathrm{L}$.

Pengamatan dilakukan setelah inkubasi selama 24 jam dan 48 jam. Densitas sel dihitung menggunakan instrumen microplate reader dengan pengukuran pada panjang gelombang UV pada $595 \mathrm{~nm}$ untuk mendapatkan absorbansi dari sel bakteri yang telah diberi perlakuan senyawa uji dan absorbansi sel bakteri yang tidak diberi perlakuan senyawa uji (kontrol). Nilai IC50 dan IC90 didapatkan dengan menghitung \%penghambatan dan dianalisis menggunakan analisis probit dengan program SPSS for Windows versi 16.0 Free Trial.

\section{Uji Efektifitas Antibakteri dengan Metode Mikrodilusi}

Persen penghambatan pertumbuhan bakteri uji dihitung dengan menggunakan persamaan sebagai berikut:

$$
\% \text { penghambatan }=\frac{O D \text { Kontrol Bakteri- }(0 \mathrm{D} \text { Larutan Uji-OD Kontrol Minyak) }}{O D \text { Kontrol Bakteri }} \times 100
$$

Keterangan: OD = Optical Density yang diamati pada panjang gelombang $595 \mathrm{~nm}$

Kemudian dianalisis dengan menggunakan analisis probit dengan program SPSS (Statistical Product of Service Solution) for Windows versi 16.0 Free Trial. Nilai KBM dinyatakan sebagai konsentrasi terkecil pada bekas goresan larutan uji yang tidak menunjukkan adanya pertumbuhan mikroba uji setelah inkubasi.

\section{HASIL DAN PEMBAHASAN}

Disc diffusion test atau uji difusi disk merupakan salah satu metode yang dapat dilakukan untuk uji efektifitas antibakteri 
yaitu dilakukan dengan cara mengukur diameter zona bening (clear zone), dimana zona bening yang muncul merupakan petunjuk adanya respon positif untuk melakukan penghambatan pertumbuhan bakteri oleh suatu senyawa antibakteri (6). Hasil uji disc diffusion test dengan seri konsentrasi $2000 \mu \mathrm{g} / \mathrm{mL}, 1000 \mu \mathrm{g} / \mathrm{mL}, 500 \mu \mathrm{g} / \mathrm{mL}, 250$ $\mu \mathrm{g} / \mathrm{mL}, 125 \mu \mathrm{g} / \mathrm{mL}, 62,5 \mu \mathrm{g} / \mathrm{mL}, 31,25 \mu \mathrm{g} / \mathrm{mL}, 15,625 \mu \mathrm{g} / \mathrm{mL}$, kontrol positif dan kontrol negatif disajikan pada Gambar 1 dan Tabel 1. Dari hasil uji dengan metode disc diffusion test yang dilakukan ini dapat diketahui bahwa setiap larutan sampel Minyak Atsiri Masoyi dengan seri konsentrasi yang berbeda-beda dapat menghasilkan zona bening (clear zone) pada area sekitar disc. Oleh karena itu, larutan sampel Minyak Atsiri Masoyi dengan seri konsentrasi yang digunakan dapat memberikan respon penghambatan pertumbuhan bakteri Streptococcus mutans.

\begin{tabular}{|c|c|c|c|c|}
\hline Disc & $\begin{array}{l}\text { Konsentrasi } \\
(\mu \mathrm{g} / \mathrm{mL})\end{array}$ & $\begin{array}{c}\text { Replikasi } \\
1 \\
(\mathrm{~mm}) \\
\end{array}$ & $\begin{array}{c}\text { Replikasi } \\
2 \\
(\mathrm{~mm}) \\
\end{array}$ & $\begin{array}{c}\text { Replikasi } \\
3 \\
(\mathrm{~mm}) \\
\end{array}$ \\
\hline 1 & 2000 & 13 & 14 & 13 \\
\hline 2 & 1000 & 12 & 14 & 13 \\
\hline 3 & 500 & 14 & 12 & 14 \\
\hline 4 & 250 & 13 & 13 & 12 \\
\hline 5 & 125 & 12 & 12 & 12 \\
\hline 6 & 62,5 & 11 & 12 & 12 \\
\hline 7 & 31,25 & 12 & 12 & 12 \\
\hline 8 & 15,625 & 12 & 12 & 12 \\
\hline P1 & $\begin{array}{l}\text { Kontrol Positif } \\
\text { (obat kumur } \\
\text { komersil) }\end{array}$ & 0 & 0 & 0 \\
\hline P2 & $\begin{array}{l}\text { Kontrol Positif } \\
\text { (antibiotik } \\
\text { ampisilin) }\end{array}$ & 17 & 20 & 18 \\
\hline N1 & Kontrol Negatif & 0 & 0 & 0 \\
\hline N2 & $\begin{array}{c}\text { Kontrol Minyak } \\
\text { (minyak atisiri } \\
\text { masoyi) }\end{array}$ & 15 & 14 & 14 \\
\hline
\end{tabular}

Hasil uji antibakteri dengan penentuan nilai KHM (Kadar Hambat Minimum) pada konsentrasi $2000 \mu \mathrm{g} / \mathrm{mL}, 1000$ $\mu \mathrm{g} / \mathrm{mL}, 500 \mu \mathrm{g} / \mathrm{mL}, 250 \mu \mathrm{g} / \mathrm{mL}, 125 \mu \mathrm{g} / \mathrm{mL}, 62,5 \mu \mathrm{g} / \mathrm{mL}$, $31,25 \mu \mathrm{g} / \mathrm{mL}, 15,625 \mu \mathrm{g} / \mathrm{mL}$ disajikan pada Gambar 2. Pada tabung 1 sampai tabung 3 dengan masing-masing konsentrasi larutan uji $2000 \mu \mathrm{g} / \mathrm{mL}, 1000 \mu \mathrm{g} / \mathrm{mL}, 500$ $\mu \mathrm{g} / \mathrm{mL}$, tampak larutan mulai jernih dan tidak tampak adanya gumpalan/selaput yang tumbuh. Sedangkan pada tabung 4 sampai tabung 8 dengan masing-masing konsentrasi larutan uji $250 \mu \mathrm{g} / \mathrm{mL}, 125 \mu \mathrm{g} / \mathrm{mL}, 62,5 \mu \mathrm{g} / \mathrm{mL}, 31,25 \mu \mathrm{g} / \mathrm{mL}, 15,625$ $\mu \mathrm{g} / \mathrm{mL}$, tampak larutan yang tidak terlalu keruh dan terdapat gumpalan/selaput yang menandakan adanya pertumbuhan bakteri Streptococcus mutans pada larutan tersebut.

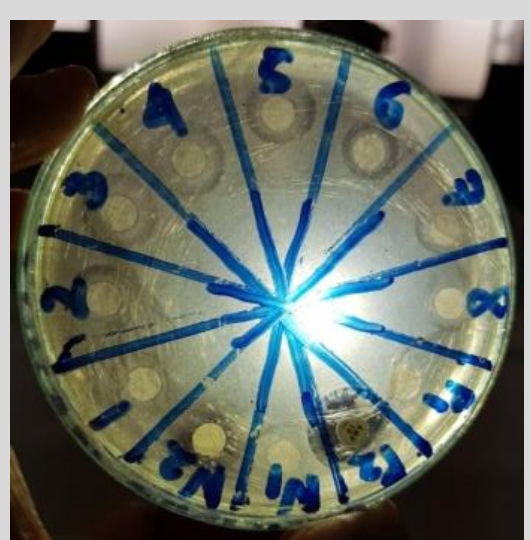

Gambar 1. Kurva persamaan regresi linier aktivitas antioksidan perasan jeruk manis.
Dari hasil yang didapatkan, dapat diketahui bahwa konsentrasi $500 \mu \mathrm{g} / \mathrm{mL}$ merupakan konsentrasi terkecil yang mampu menghambat pertumbuhan bakteri Streptococcus mutans. Hal tersebut ditunjukkan dengan warna larutan tidak keruh dan tidak adanya gumpalan/selaput biofilm yang terbentuk di dalam larutan. Dengan demikian, larutan sampel pada tabung 3 yaitu larutan uji dengan seri konsentrasi minyak atisiri masoyi $500 \mu \mathrm{g} / \mathrm{mL}$ dapat dinyatakan sebagai nilai KHM.
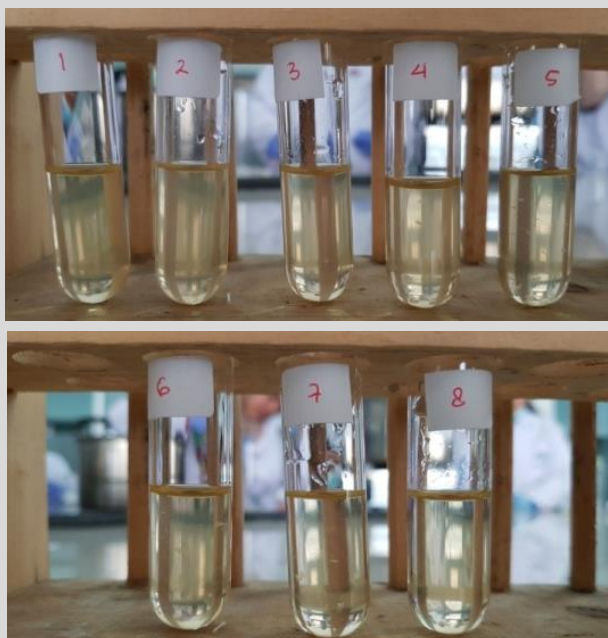

Gambar 2. Hasil Uji Penentuan Nilai KHM.

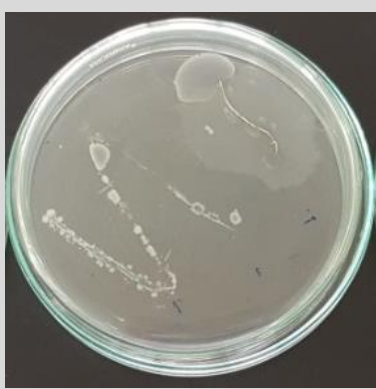

$2000 \mu \mathrm{g} / \mathrm{mL}$

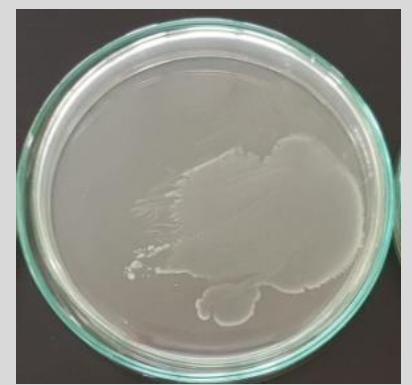

$1000 \mu \mathrm{g} / \mathrm{mL}$

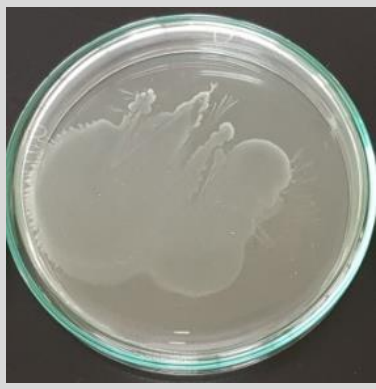

$500 \mu \mathrm{g} / \mathrm{mL}$

Gambar 3. Hasil Uji Penentuan Nilai KBM.

Penentuan nilai KBM (Kadar Bunuh Minimum) pada penelitian ini dilakukan dengan menggunakan larutan uji dengan tiga konsentrasi dari uji penentuan KHM yaitu 2000 $\mu \mathrm{g} / \mathrm{mL}, 1000 \mu \mathrm{g} / \mathrm{mL}$, dan $500 \mu \mathrm{g} / \mathrm{mL}$ karena tiga konsentrasi 
tersebut yang menunjukkan adanya kemampuan untuk menghambat pertumbuhan bakteri pada uji penentuan nilai KHM yang dilakukan sebelumnya. Dengan menggunakan konsentrasi yang sudah diketahui bahwa memiliki kemampuan untuk menghambat pertumbuhan bakteri Streptococcus mutans tersebut, diharapkan media agar tetap jernih yang berarti larutan uji dengan masing-masing seri konsentrasi yang diberikan dapat membunuh bakteri Streptococcus mutans. Hasil uji penentuan nilai KBM dengan konsentrasi $2000 \mu \mathrm{g} / \mathrm{mL}, 1000 \mu \mathrm{g} / \mathrm{mL}, 500 \mu \mathrm{g} / \mathrm{mL}$ disajikan pada Gambar 3.

Setelah diinkubasi selama 1 hari (24 jam), didapatkan hasil dari uji penentuan nilai KBM yang ditunjukkan pada Gambar 3. Hasil yang didapatkan diamati secara visual secara langsung. Hasil tersebut menunjukkan bahwa pada semua cawan petri yang sudah diisi dengan media NA dan digores dengan larutan sampel dengan masing-masing konsentrasi yang digunakan, bakteri Streptococcus mutans masih dapat bertumbuh yang ditandai dengan munculnya bercak-bercak pada media NA yang digunakan. Pada konsentrasi tertinggi yang digunakan yaitu $2000 \mu \mathrm{g} / \mathrm{mL}$ pada penelitian ini, bakteri Streptococcus mutans juga masih dapat beradaptasi dan bertumbuh. Hal tersebut menunjukkan bahwa semua konsentrasi yang digunakan pada penelitian ini tidak mampu untuk membunuh bakteri Streptococcus mutans. Dengan demikian, nilai KBM pada penelitian ini dapat dinyatakan lebih besar dari konsentrasi $2000 \mu \mathrm{g} / \mathrm{mL}$.

Metode mikrodilusi merupakan pengembangan dari metode dilusi cair yang menggunakan media, bakteri, dan senyawa uji dalam jumlah yang sedikit dan menggunakan alat microplate 96 wells. Pada metode ini kekeruhan dari larutan pada microplate 96 wells diamati sebagai nilai kerapatan optik (optical density/OD) dengan menggunakan instrumen microplate reader yang diaplikasikan dalam nilai absorbansi. Pada penelitian ini dilakukan uji efektifitas antibakteri dengan metode kuantitatif untuk mendapatkan nilai IC $_{50}$ (inhibitor concentration 50\%) dan $\mathrm{IC}_{90}$ (inhibitor concentration 90\%). Semakin kecil nilai $\mathrm{IC}_{50}$ dan $\mathrm{IC}_{90}$ maka semakin potensial efek hambat ekstrak tersebut dalam menghambat pembentukan bakteri. Dengan diketahuinya nilai $\mathrm{IC}_{50}$ dan $\mathrm{IC}_{90}$ maka dapat menyimpulkan data konsentrasi yang lebih akurat dalam kemampuan sampel untuk menghambat dan membunuh bakteri.

Pada penelitian ini digunakan dua microplate, microplate pertama digunakan untuk sampel dengan inkubasi selama 24 jam, sedangkan microplate kedua digunakan untuk sampel dengan inkubasi selama 48 jam. Hal tersebut dilakukan untuk mengetahui perbedaan besar pertumbuhan bakteri dengan inkubasi selama 24 jam dan dengan inkubasi selama 48 jam. Hasil nilai rata-rata absorbansi/OD pertumbuhan bakteri dengan inkubasi selama 24 jam ditunjukkan pada Gambar 4 , sedangkan hasil nilai rata-rata absorbansi/OD pertumbuhan bakteri dengan inkubasi selama 48 jam ditunjukkan pada Gambar 5.

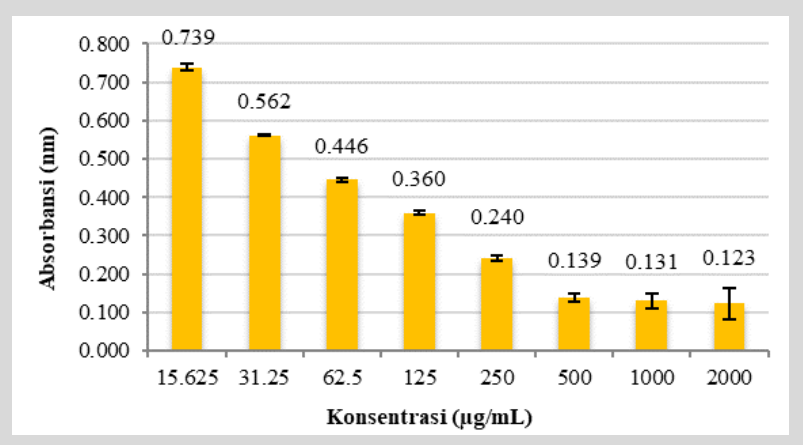

Gambar 4. Hasil Skrining (Inkubasi 24 Jam)
Setelah diinkubasi selama 1 hari (24 jam), didapatkan hasil dari uji penentuan nilai KBM yang ditunjukkan pada gambar 3. Hasil yang didapatkan diamati secara visual secara langsung. Hasil tersebut menunjukkan bahwa pada semua cawan petri yang sudah diisi dengan media NA dan digores dengan larutan sampel dengan masing-masing konsentrasi yang digunakan, bakteri Streptococcus mutans masih dapat bertumbuh yang ditandai dengan munculnya bercak-bercak pada media NA yang digunakan. Pada konsentrasi tertinggi yang digunakan yaitu $2000 \mu \mathrm{g} / \mathrm{mL}$ pada penelitian ini, bakteri Streptococcus mutans juga masih dapat beradaptasi dan bertumbuh. Hal tersebut menunjukkan bahwa semua konsentrasi yang digunakan pada penelitian ini tidak mampu untuk membunuh bakteri Streptococcus mutans. Dengan demikian, nilai KBM pada penelitian ini dapat dinyatakan lebih besar dari konsentrasi $2000 \mu \mathrm{g} / \mathrm{mL}$.

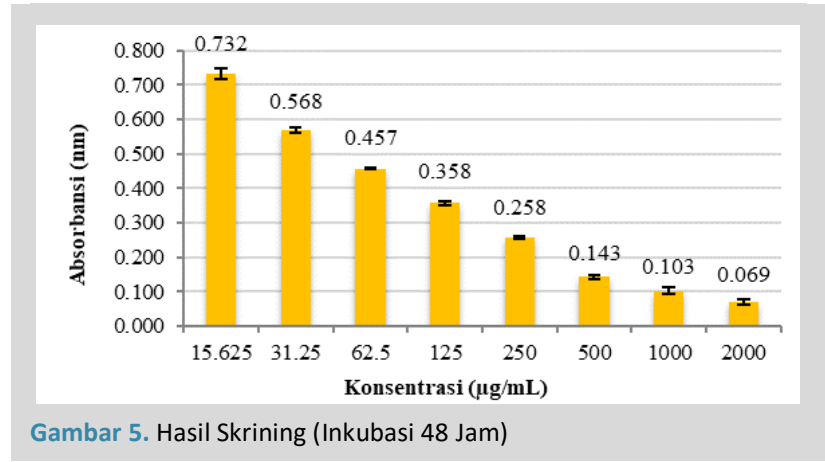

Metode mikrodilusi merupakan pengembangan dari metode dilusi cair yang menggunakan media, bakteri, dan senyawa uji dalam jumlah yang sedikit dan menggunakan alat microplate 96 wells. Pada metode ini kekeruhan dari larutan pada microplate 96 wells diamati sebagai nilai kerapatan optik (optical density/OD) dengan menggunakan instrumen microplate reader yang diaplikasikan dalam nilai absorbansi. Pada penelitian ini dilakukan uji efektifitas antibakteri dengan metode kuantitatif untuk mendapatkan nilai $\mathrm{IC}_{50}$ (inhibitor concentration 50\%) dan IC $_{90}$ (inhibitor concentration 90\%). Semakin kecil nilai IC $_{50}$ dan IC 90 maka semakin potensial efek hambat ekstrak tersebut dalam menghambat pembentukan bakteri. Dengan diketahuinya nilai $\mathrm{IC}_{50}$ dan $\mathrm{IC}_{90}$ maka dapat menyimpulkan data konsentrasi yang lebih akurat dalam kemampuan sampel untuk menghambat dan membunuh bakteri.

\begin{tabular}{|c|c|c|c|}
\hline $\begin{array}{c}\text { Konsentrasi } \\
(\mu \mathrm{g} / \mathrm{mL})\end{array}$ & $\begin{array}{l}\text { OD Larutan } \\
\text { (nm) }\end{array}$ & SD & $\begin{array}{c}\% \\
\text { Penghambatan } \\
(\%)\end{array}$ \\
\hline 15,625 & 0,739 & 0,0074 & 2,166 \\
\hline 31,25 & 0,562 & 0,0017 & 29,281 \\
\hline 62,5 & 0,446 & 0,0046 & 47,018 \\
\hline 125 & 0,360 & 0,0042 & 60,219 \\
\hline 250 & 0,240 & 0,0068 & 78,466 \\
\hline 500 & 0,136 & 0,0115 & 93,960 \\
\hline 1000 & 0,131 & 0,0021 & 95,260 \\
\hline 2000 & 0,123 & 0,0049 & 96,483 \\
\hline
\end{tabular}

Pada penelitian ini digunakan dua microplate, microplate pertama digunakan untuk sampel dengan inkubasi selama 24 jam, sedangkan microplate kedua digunakan untuk sampel dengan inkubasi selama 48 jam. Hal tersebut dilakukan untuk mengetahui perbedaan besar pertumbuhan bakteri dengan inkubasi selama 24 jam dan dengan inkubasi selama 48 jam. Hasil nilai rata-rata absorbansi/OD pertumbuhan bakteri dengan inkubasi selama 24 jam ditunjukkan pada gambar 4 , sedangkan hasil nilai rata-rata absorbansi/OD pertumbuhan bakteri dengan inkubasi selama 48 jam ditunjukkan pada Gambar 5. 
Dari data skrining tersebut juga dapat diketahui besar nilai rata-rata absorbansi/OD dan dapat dihitung besar nilai \% penghambatan untuk masing-masing konsentrasi yang digunakan. Nilai absorbansi/OD untuk tiap konsentrasi dapat dihitung dari rata-rata dari empat replikasi larutan uji dari masing-masing konsentrasi. Sedangkan besar nilai \% penghambatan untuk tiap konsentrasi dapat dihitung dengan persamaan $\%$ penghambatan. Hasil besar nilai absorbansi/OD dan besar nilai \% penghambatan pada perlakukan dengan inkubasi 24 jam untuk tiap konsentrasi ditunjukkan pada Tabel 2, sedangkan Hasil besar nilai absorbansi/OD dan besar nilai \% penghambatan pada perlakukan dengan inkubasi 48 jam untuk tiap konsentrasi ditunjukkan pada Tabel 3.

\begin{tabular}{|c|c|c|c|}
\hline $\begin{array}{c}\text { Konsentrasi } \\
(\mu \mathrm{g} / \mathrm{mL})\end{array}$ & $\begin{array}{l}\text { OD Larutan } \\
\text { (nm) }\end{array}$ & SD & $\begin{array}{c}\% \\
\text { Penghambatan } \\
(\%)\end{array}$ \\
\hline 15,625 & 0,732 & 0,0156 & 12,940 \\
\hline 31,25 & 0,568 & 0,0081 & 35,642 \\
\hline 62,5 & 0,457 & 0,0025 & 50,853 \\
\hline 125 & 0,358 & 0,0047 & 64,594 \\
\hline 250 & 0,258 & 0,0046 & 78,335 \\
\hline 500 & 0,143 & 0,0070 & 94,190 \\
\hline 1000 & 0,107 & 0,0085 & 99,153 \\
\hline 2000 & 0,105 & 0,0079 & 99,498 \\
\hline
\end{tabular}

Berdasarkan hasil yang ditunjukkan pada Tabel 2, dapat dilihat bahwa dengan perlakuan inkubasi selama 24 jam didapatkan hasil semakin tinggi konsentrasi maka nilai absorbansi/OD dari larutan uji semakin rendah (berbanding terbalik). Sedangkan untuk nilai \% penghambatan, semakin tinggi konsentrasi maka semakin tinggi juga nilai \% penghambatan (berbanding lurus). Hal tersebut menunjukkan bahwa semakin tinggi konsentrasi yang digunakan, maka semakin besar juga kemampuan Minyak Atsiri Masoyi sebagai antibakteri. Setelah diperoleh hasil data $\%$ penghambatan, nilai $\mathrm{IC}_{50}$ dan $\mathrm{IC}_{90}$ (inkubasi 24 jam) ditentukan dengan analisis probit menggunakan program Statistical Package for the Social Sciences (SPSS) versi 16 Hasil analisis probit yang menunjukkan nilai IC $_{50}$ dan IC 90 (inkubasi 24 jam) ditunjukkan pada tabel 4, sedangkan hasil analisis probit yang menunjukkan nilai $\mathrm{IC}_{50}$ dan $\mathrm{IC}_{90}$ (inkubasi 48 jam) ditunjukkan pada Tabel 5.

\begin{tabular}{ccc}
\hline Tabel 4. Hasil Analisis Probit (24 Jam) & \\
\hline $\begin{array}{c}\text { Bakteri } \\
\begin{array}{c}\text { Streptococcus } \\
\text { mutans }\end{array}\end{array}$ & $\begin{array}{c}\mathrm{IC}_{50} \\
(\mu \mathrm{g} / \mathrm{mL})\end{array}$ & $\begin{array}{c}\mathrm{IC}_{90} \\
(\mu \mathrm{g} / \mathrm{mL})\end{array}$ \\
\cline { 2 - 3 } & 85,047 & 491,481 \\
\hline \begin{tabular}{c} 
Tabel 5. Hasil Analisis Probit (48 Jam) \\
\hline $\begin{array}{c}\text { Btreptococcus } \\
\text { mutans }\end{array}$
\end{tabular} & $\begin{array}{c}\mathrm{IC}_{50} \\
(\mu \mathrm{g} / \mathrm{mL})\end{array}$ & $\begin{array}{c}\mathrm{IC}_{90} \\
(\mu \mathrm{g} / \mathrm{mL})\end{array}$ \\
\hline & 64,849 & 383,908 \\
\hline
\end{tabular}

Dari hasil yang ditunjukkan pada tabel 4, dapat dilihat bahwa nilai IC 50 adalah $85,047 \mu \mathrm{g} / \mathrm{mL}$ dan nilai IC 90 adalah 491,481 $\mu \mathrm{g} / \mathrm{mL}$. Dengan nilai $\mathrm{IC}_{50}=85,047 \mu \mathrm{g} / \mathrm{mL}$, berarti pada konsentrasi larutan uji sebesar 85,047 $\mu \mathrm{g} / \mathrm{mL}$ dapat menghambat pertumbuhan bakteri sebanyak $50 \%$. Sedangkan dengan nilai $\mathrm{IC}_{90}=491,481 \mu \mathrm{g} / \mathrm{mL}$, berarti pada konsentrasi larutan uji sebesar 491,481 $\mu \mathrm{g} / \mathrm{mL}$ dapat menghambat pertumbuhan bakteri sebanyak $90 \%$.

Dari hasil yang ditunjukkan pada tabel 5, dapat dilihat bahwa nilai IC50 adalah $64,849 \mu \mathrm{g} / \mathrm{mL}$ dan nilai IC90 adalah 383,908 $\mu \mathrm{g} / \mathrm{mL}$. Dengan nilai $\mathrm{IC}_{50}=64,849 \mu \mathrm{g} / \mathrm{mL}$, berarti pada konsentrasi larutan uji sebesar 64,849 $\mu \mathrm{g} / \mathrm{mL}$ dapat menghambat pertumbuhan bakteri sebanyak $50 \%$. Sedangkan dengan nilai $\mathrm{IC}_{90}=383,908 \mu \mathrm{g} / \mathrm{mL}$, berarti pada konsentrasi larutan uji sebesar 383,908 $\mu \mathrm{g} / \mathrm{mL}$ dapat menghambat pertumbuhan bakteri sebanyak $90 \%$.

Dari pengujian antibakteri dengan metode kualitatif dan kuantitatif tersebut dapat dinyatakan bahwa Minyak Atsiri Masoyi (Massoia aromatica) dapat efektif digunakan sebagai antibakteri Streptococcus mutans. Adanya penurunan jumlah koloni bakteri yang tumbuh seiring dengan peningkatan konsentrasi Minyak Atsiri Masoyi, hal tersebut membuktikan bahwa adanya efek penghambatan pertumbuhan bakteri Streptococcus mutans. Kadar penghambatan pertumbuhan bakteri minimum yang dihasilkan pada metode kualitatif dan kuantitatif (inkubasi 24 jam) memiliki hasil yang mirip/berdekatan yaitu nilai IC 90 sebesar $491,481 \mu \mathrm{g} / \mathrm{mL}$ dan nilai KHM (uji kualitatif) sebesar $500 \mu \mathrm{g} / \mathrm{mL}$. Dengan demikian, konsentrasi minyak atsiri lebih dari $490 \mu \mathrm{g} / \mathrm{mL}$ dapat digunakan untuk menghambat pertumbuhan bakteri Streptococcus mutans.

Secara umum, minyak atsiri bekerja dengan mengganggu intergritas membran sel bakteri yaitu menyebabkan kebocoran elektrolit dan komponen utama penyusun sel seperti protein, penurunan kadar gula dan ATP pada sel sehingga menghambat pembentukan ATP. Senyawa bioaktif pada minyak atsiri menempel pada permukaan sel bakteri dan berpenetrasi melalui fosfolipid bilayer pada membran sel sehingga mengganggu intergritas sel dan akan memengaruhi metabolisme sel tersebut (7). Senyawa masoilakton mengandung cincin lakton dan termasuk golongan terpen lakton (8). Mekanisme terpenoid sebagai antibakteri adalah bereaksi dengan porin (protein transmembran) pada membran luar dinding sel bakteri (5), membentuk ikatan polimer yang kuat sehingga mengakibatkan rusaknya porin, mengurangi permeabilitas dinding sel bakteri sehingga membuat sel bakteri kekurangan nutrisi yang akan mengakibatkan pertumbuhan bakteri terhambat atau mati (3).

\section{KESIMPULAN}

Secara kualitatif, nilai Kadar Hambat Minimum (KHM) Minyak Atsiri Masoyi terhadap bakteri Streptococcus mutans adalah $500 \mu \mathrm{g} / \mathrm{mL}$ dan nilai Kadar Bunuh Minimum (KBM) Minyak Atsiri Masoyi terhadap bakteri Streptococcus mutans adalah lebih dari $2000 \mu \mathrm{g} / \mathrm{mL}$. Secara kuantitatif, nilai IC50 Minyak Atsiri Masoyi terhadap bakteri Streptococcus mutans adalah 85,047 $\mu \mathrm{g} / \mathrm{mL}$ dan IC90 Minyak Atsiri Masoyi terhadap bakteri Streptococcus mutans adalah 491,481 $\mu \mathrm{g} / \mathrm{mL}$

\section{DAFTAR PUSTAKA}

1. Yuliandari, R., 2015, Uji Aktivitas Sari Buah Belimbing Wuluh (Averrhoa bilimbi L.) Terhadap Biofilm Pseudomonas aeruginosa Secara In Vitro, Skripsi S-1, Fakultas Kedokteran dan Ilmu Kesehatan, Program Studi Farmasi, UIN Syarif Hidayatullah, Jakarta.

2. Ogawa, A., et al, 2011, Inhibition of Streptococcus mutans Biofilm Formation by Streptococcus salivarius FruA, Applied and Environmental Microbiology, 77(5):1572-1580.

3. Pratiwi, S.U.T, Lagendijk, E.L, Weert, S. de, Hertiani, T., Idroes, R., dan Hondel, C.A.V.D., 2015, Effect of Cinnamomum burmannii Nees ex Bl. and Massoia aromatica Becc. Essential Oils on Planktonic Growth and Biofilm formation of Pseudomonas aeruginosa and Staphylococcus aureus In Vitro, International Journal of Applied Research in Natural Products, Vol 8, Hal 1-13

4. Haryati, A.N., Saleh, C., Erwin, 2015, Uji Toksisitas Dan Aktivitas Antibakteri Ekstrak Daun Merah Tanaman Pucuk Merah (Syzygium myrtifolium Walp.) Terhadap Bakteri Staphylococcus aureus Dan Escherichia coli, Jurnal Kimia Mulawarman, 13(1):35-40.

5. Hermawan, A., Hana, W., dan Wiwiek, T. 2007. Pengaruh Ekstrak Daun Sirih (Piper betle L.) Terhadap Pertumbuhan Staphylococcus aureus dan Escherichia coli dengan Metode Difusi Disk. Universitas Erlangga.

6. Rali, T., Wossa, S.W., dan Leach, D.N., 2007, Comparative Chemical Analysis of the Essential Oil Constituents in the Bark, Heartwood and 
Fruits of Cryptocarya massoia (Oken) Kosterm. (Lauraceae) from Papua New Guinea, Molecules, Vol 12, Hal 149-154.

7. Rollando, Sitepu, R., 2018, Efek Antibakteri Dari Kombinasi Minyak Atsiri Masoyi dan Kayu Manis, Jurnal Kefarmasian Indonesia, 8(1):26 - 33
8. Triatmoko, B., Hertiani, T., Yuswanto, A., 2016, Sitotoksisitas Minyak Mesoyi (Cryptocarya masoy) Terhadap Sel Vero, E-Jurnal Pustaka Kesehatan, $4(2)$ 